В. М. Борита

здобувач кафедри української мови

\title{
СПОНУКАЛЬНІ КОНСТРУКЦІЇ ЯК ОДНА IЗ СТРУКТУРНО-СЕМАНТИЧНИХ І ФУНКЦІОНАЛЬНИХ ОСОБЛИВОСТЕЙ ТЕКСТІВ ЦЕРКОВНИХ ПРОПОВІДЕЙ
}

Дослідження присвячено аналізу семантико-синтаксичних та функиіональних особливостей спонукальних конструкцій у текстах иерковних проповідей, розгляду мовних засобів на позначення спонукальності.

Сучасні суспільні умови сприяють повноцінному становленню всіх засобів мовної організації конфесійного стилю, розвиток якого упродовж майже цілого століття був призупинений, що пов'язано з витісненням релігії з усіх сфер громадського та наукового життя України.

У 30-х роках XX ст. відбувається радянізація суспільства, яка не могла співіснувати 3 церквою та їі культом, а тому усе церковне забороняється $\mathrm{i}$ витісняється за межі суспільного «радянського» життя України. Це стає основною причиною втрати конфесійним стилем усіх прав на повноцінний розвиток і на належне грунтовне дослідження. Відповідно й удосконалення його в цей час уповільнюється. Однак, незважаючи на утиски і заборони, конфесійний стиль розвивається у зв'язку з діяльністю Української автокефальної православної церкви під орудою Василя Липківського.

Стійким осередком розвитку стилю на той час стає діаспора, де були українські релігійні громади. Представники діаспори (О. Горбач, Є. Грицак, Ю. Луцик, І. Огієнко, П. Ковалів та ін.) зуміли зберегли безперервність історії конфесійного стилю. Ними видавалися катехезиси, молитовники, проповіді і послання, вийшла друком Біблія українською мовою в перекладі Івана Огієнка [4, 19-20].

У самій же Україні протягом тривалого періоду так званого застою конфесійний стиль функціонував переважно в усній формі. Це стосується як церковно-релігійних обрядових дійств, так і деяких його окремих елементів - молитов, піснеспівів, читання священних книг. Відсутність конфесійного стилю в традиційних класифікаціях свідчить про те, що він не підлягав науковому дослідженню, а в лексикографічних джерелах мовні елементи стилю фіксувалися, зазвичай, з позначкою «застаріле» [3, 21].

Сьогодні спостерігаємо сплеск уваги до конфесійного стилю: з'являються дослідження 3 проблеми стилю (Н. Бабич, С. Бібла, Н. Дзюбишина-Мельник, В. Німчук, І. Павлова, Н. Пуряєва та ін.), проводиться велика лексикографічна робота, пов'язана 3 упорядкуванням церковних термінів. Цьому сприяє поява значної кількості богословської літератури українською мовою. Дослідженням текстів сучасних українських церковних проповідей займаються С. Гарбуз, С. Кот, З. Кунь, О. Петришина. 
Метою нашої розвідки є з'ясування структурно-семантичних та функціональних особливостей спонукальних конструкцій текстів сучасних церковних проповідей.

Актуальність статті зумовлена тим, що конфесійний стиль на сучасному етапі розвитку мовознавства є найменше дослідженим. Про це свідчить наявність лише окремих вкраплень і спостережень розвитку стилю у вигляді заміток і статей у періодичних виданнях та відсутність системи монографічних досліджень, пов'язаних із ним. Причиною недостатнього дослідження конфесійного стилю $є$ табуювання українських національних форм християнських віровчень і віросповідань протягом останніх століть, а також вилучення із загального вжитку релігійної літератури українською мовою. Тому цілком закономірним, на нашу думку, є аналіз структурносемантичних та функціонально-прагматичних особливостей спонукальних конструкцій текстів церковних проповідей.

«Проповідницький підстиль, або підстиль церковної проповіді, - це різновид релігійного стилю сучасної української мови, який, зберігаючи домінантні риси останнього, характеризується виразними позамовними i власне мовно-структурними особливостями, пов'язаними з метою висловлювання та специфікою комунікативного акту. Вирізняється підстиль церковної проповіді й синтаксичними засобами організації тексту» $[5,6]$.

Комунікативна організація текстів проповідей визначається передусім тим, що вона спрямована не у сферу мови, а у сферу мовлення. За характером мовленнєвого стимулу в проповіді варто виділити риторичність, спонукальність, звернення до адресатів, що стимулює активізацію духовної або фізичної діяльності останніх.

До спонукальних М. У. Каранська відносить речення, «що виражають вольові стосунки мовця з виконавцем: перший спонукає щось робити або не робити, а другий має здійснювати визначене» $[2,17]$. Саме тому в таких реченнях цілком природним $є$ присудок у формі наказового способу другої особи однини або множини. За С. Бевзенком, спонукальні (імперативні) речення виражають волю або намагання мовця спонукати співрозмовника до якоїсь дії. Вони набувають граматичного оформлення за допомогою різних форм вираження присудка, особливої інтонації та використання спеціальних спонукальних часток $[1,39]$.

Спонукальні конструкції здатні виражати більшу чи меншу спрямованість на виконавця, а тому їх можна класифікувати на безпосередньо спонукальні та опосередковано спонукальні. До перших, у такому випадку, належатимуть спонукання, що виражають заклики, заборони, вимоги, накази тощо; до других (опосередкованих) - спонукання, які виражають прохання, поради, заохочення, благання, застереження тощо $[1,40]$.

Здійснене дослідження свідчить про те, що для текстів церковних проповідей властивими є лише опосередковані спонукальні конструкції. 
Для спонукальних конструкцій текстів проповідей, як і для всіх спонукальних речень, найхарактернішим є вживання спонукальних речень, що звернені до другої особи або осіб, які виконуватимуть сказане. При цьому названа в таких реченнях дія не завжди безпосередньо стосується співрозмовника, вона може торкатися будь-кого, носити узагальнене значення, наприклад: Не гнівайся на жодну людину, хоч як би вона тебе не образила (4, 69); Прийдіть, поклоніться священним образам Христа, Пречистої Його Матері і святих і відкиньте злочесну віру тих, хто лихословить $(4,379)$.

Семантика спонукальних речень у проповідях часто зумовлює появу в їх структурі звертань - назв осіб, рідше - інших абстрактних понять. Звертання в цих реченнях можуть бути виражені як окремими словами: Господи! Я не достойний, щоб ти увійшов під покрівлю мою... $(4,108)$, так і словосполученнями: Христе Iсусе, Світло істини, просвіти нас світлом розуму Євангелія Твого $(4,314)$. Найуживанішими в текстах проповідей $\epsilon$ звертання «Дорогі браття і сестри!», які виступають початковими структурно-семантичними компонентами кожної проповіді.

Спонукальні конструкції, що вживаються в текстах проповідей, дуже різноманітні за своєю семантикою, зокрема, вони виражають:

- прохання з відтінками поради, наприклад: Не уподібнюйтесь, браття і сестри, тим, хто, сідаючи за стіл, не молиться Богу $(4,137)$; чи побажання, специфічною ознакою яких є вживання дієслів у формі першої особи множини та використання підсилювальних часток: $B$ ией день простімо один одного Воскресінням Христовим і будемо благати Господа, щэоб Він зміцнив Своєю Божественною благодаттю намі душевні і тілесні сили $i$ благословив нас на добрі справи $(4,47) ;$ Не будемо жс забувати заповідь Господа нашого Ісуса Христа: "Шукайте ж спериу Царства Божсого і правди Його, і все ие додасться вам» (Мф. 6, 33) (4, 107);

- прохання-вимоги, заохочення й заклики, яким притаманне підвищене емоційне забарвлення й окличність: Не будемо, дорогі браття і сестри, оскверняти благочестиві древні православні звичаї недостойною поведінкою на священних могилах наших померлих! (4, 56); Браття $і$ сестри! Опам'ятаймося $і$ покаймося! (4, 347); Віруйте в єдиного Бога-Отия, $i$ Сина, і Святого Духа! Звеличуйте Трисвяте, Трисяйне і Триіпостасне Божество! Поклоняйтеся Живо начальній, Всемогутній $і$ Нероздільній Tройиi! $(4,88)$;

- прохання, що виражають відтінок благання, здебільшого такі конструкції супроводжуються звертаннями з вигуками: О Господи! Навчи нас любити Тебе так, як любили Тебе Твої щирі друзі-ученики $(4,189)$;

- застереження: Коли люди неосвічені кажуть, щэо у такому-то храмі немає благодаті, - не вірте! Благодать Божа перебуває у всякому православному християнині, який жадає иієї благодаті (4, 100); застереження, у яких для активації співрозмовників використовуються вставні слова, напри- 
клад: Дорогі браття і сестри! Пам'ятаймо, сила злих духів міџна, а наша сила немічна $(4,57)$.

Характерними в проповідях є спонукальні конструкції, що виражають заповіді: Недаремно Бог дав людям четверту заповідь: «Пам'ятай день суботній, щзоб святити його» $(4,276)$.

Типовими для текстів проповідей $є$ конструкції, у яких автор (проповідник), звертаючись до другої особи або осіб, що виконуватимуть сказане, i сам пропонує взяти участь у виконанні спонукання, тому імператив у таких реченнях набуває, як правило, вираження форми першої особи множини: Будемо поблажливими одне до одного і прощатимемо взаємно, якщо хто на кого має гнів або образу $(4,162)$. Нерідко спонукання в таких конструкціях супроводжується підсилювальними частками: Будемо $\underline{\boldsymbol{\mu c}}$ радіти, щуо Господь наш Ісус Христос дав нам таке досконале моральне вчення $(4,226)$.

Серед спонукальних у проповідях наявні речення, що виражені модальною бажальністю, яку передають безособові конструкції з модальним словом: Треба боятися гріха більш за все на світі $(4,67)$; Треба кожному $з$ нас брати за взірець буття Господа намого Iсуса Христа $(4,296)$.

Поширеними в текстах проповідей є спонукальні конструкції, які мають форми третьої особи однини наказового способу й утворюються за допомогою часток хай та нехай, що в значення спонукання вносять відтінки заклику, заохочення тощо: Хай Господь, щчо воскрес із мертвих, наповнює намі душі духовною радістю, вселяе в намі серия мир $i$ злагоду $(4,47)$; Тяжко боротися з гнівом, але треба. Нехай дійсно сонце не заходить у гніві нашому $(4,72)$.

Для текстів проповідей характерними $є$ конструкції з повторюваними початковими синтаксичними структурами, зокрема складні конструкції, об'єднані спільним спонукальним компонентом, наприклад: Згадаймо, щз перша натхнена пісня Богові була складена жінкою; Згадаймо Прискіллу, котру апостол Павло у Посланні до Римлян вітає як співпрацівницю...; Згадаймо Моніку - шановану матір видатного Августина; Згадаймо Анфусу матір святого Іоана Золотоустого; Згадаймо святих мученииь Віру, Надію, Любов, Софію, Скатерину... (4, 58-60).

Таким чином, для текстів проповідей характерними $є$ опосередковані спонукальні конструкції, які виражають прохання, поради, заохочення, благання, застереження тощо; спонукальна інтонація, що виступає важливим засобом оформлення спонукальних конструкцій. Функціональні особливості проповідей визначаються зверненнями до адресатів, які стимулюють активізацію їх духовної або фізичної діяльності.

\section{Список використаної літератури}

1. Бевзенко С. П. та ін. Сучасна українська мова. Синтаксис: Навч. посіб. С. П. Бевзенко, Л. П. Литвин, Г. В. Семеренко. - К.: Вища шк., 2005. - 270 с.

2. Каранська М. У. Синтаксис сучасної української літературної мови: Навч. посіб. - К.: Либідь, 1995. - 312 с. 
3. Павлова І. Лексика конфесійного стилю // Дивослово. - 2003. - №1. - С. 18-24.

4. Патріарх Філарет Проповіді. - У 2-х т. - К.: ВВ УПЦ Київського Патріархату, 1999. - T. 1. $-535 \mathrm{c}$.

5. Петришина О.І. Мова проповідей Йосифа Сліпого: Автореф. дис... канд. філол. наук. - Івано-Франківськ, 2008. - 20 с.

\section{Summary}

The article deals with the functional peculiarities of imperative structures as they appear in church sermons, using a synthetic and semantic analysis. 